Article

\title{
Legitimacy for Sustainability: A Case of A Strategy Change for An Oil and Gas Company
}

\author{
Tahrir Jaber *(1) and Elin M. Oftedal \\ School of Business and Economics, UiT-The Arctic University of Norway, N-9037 Tromsø, Norway; \\ elin.m.oftedal@uit.no \\ * Correspondence: tahrir.jaber@uit.no
}

Received: 9 November 2019; Accepted: 7 January 2020; Published: 10 January 2020

\begin{abstract}
This study introduces and validates a measure of a company's institutional profile for sustainability. It uses institutional theory as a lens to understand the factors that legitimize the adoption of renewable energy activities in an oil and gas company. The three institutional dimensions used in this study are regulative, normative and cognitive, which aimed to measure legitimacy in an oil and gas company under a sustainable change. Survey-based research was carried out among employees to test this theory. Moreover, structural equation modeling was used to test the model fit, validate the measures, and test the four hypotheses. The results showed that regulative and normative pillars play the main role in legitimating renewable energy practices in our case company. The findings provide researchers and companies with a valuable resource for exploring legitimacy in order to understand what makes companies legitimize new sustainable activities that are outside the companies' core business.
\end{abstract}

Keywords: validity; model fit; legitimacy; institutional theory; sustainability; oil and gas industry.

\section{Introduction}

In today's world, companies are pushed to adopt social and environmental responsibilities within their strategies and management systems [1,2]. Some companies have developed their own activities in order to produce more sustainable ones. Other companies have chosen to develop new sustainable activities and enter new markets. Thus, this approach has become a key item on the management agenda, and caused stakeholders to adjust their expectations of companies [3,4]. However, established companies require more work on developing their legitimacy when introducing new technologies [5-7].

The starting point of understanding legitimacy and the legitimation process was developed by Suchman [8], who explained "how the organization is built, how it is run, and simultaneously, how it is understood and evaluated". However, we know little about how established companies carry out sustainability in practice $[9,10]$, how possible initiatives are engaged in $[4,9]$, and how companies legitimate their new technologies during an institutional change [11]. Therefore, the objective of this paper was to examine the emergence of legitimacy in an established company under a sustainable change.

There is a tendency to use sustainability for symbolic purposes (to enhance reputation or build a public image), but not necessarily involve substantial changes in the organization [12]. Thus, even if sustainability is used in a company's strategy plan and rhetoric, it still might not trickle down into the organization and might remain on the surface. This leads to a problem as companies are then judged on false premises. Another complexity of sustainable transition belongs to measuring sustainability. It is argued that measuring sustainability is seen as a challenging task since it is difficult to implement and there is no specific goal to obtain when introducing sustainability within companies $[13,14]$. In an attempt to examine how an established company legitimizes its new sustainable activities, a 
clear definition of this concept and its key dimensions is needed. It is argued that companies must be perceived as legitimate to meet and balance the expectations of different stakeholders such as employees, suppliers, customers, investors, and society as a whole $[15,16]$. Thus, legitimacy is divided into two categories, internal and external. Internal legitimacy, on one hand refers to how people in companies direct the actions that would be beneficial for their companies [17]. On the other hand, external legitimacy deals with organizational fields, regulatory agencies, professional associations, and reputation $[18,19]$.

External legitimacy has an impact on companies, triggering them to change in order to maintain good standards for the society as a whole [20]. However, pursuing clean technologies in companies requires the companies' internal resources to undergo a sustainable change because companies are responsible internally for framing their identity and shaping their strategic direction $[17,21]$. Thus, we believe that studying internal legitimacy in companies undergoing change is essential in order to understand the process of their legitimacy creation.

Thus, this paper builds on work done on legitimacy and creates a measure of an organization's internal legitimacy of sustainability. In the present study, we explore this topic by addressing the following research question: 'How does an established company build internal legitimacy for investment in clean technologies under conditions of institutional change'. This question is critical to our knowledge of legitimacy, and helps us understand the process of legitimating new sustainable technologies in an established company.

Institutional theory and its core pillars (regulative, normative, and cognitive) are used within the context of an established oil and gas (OG) company. However, researchers have proven that institutional theory changes in character and potency over time, and this requires more research in order to investigate the diversity of viewpoints within the domain of the boundaries of institutional theory [22].

In this study, our context is the OG sector. OG companies belong to industries that, in the common conception, are contradictive to the sustainability imperative. OG companies are included in this category where their core competence and products are finite and, by definition, not sustainable. In fact, there has long been a dilemma in the OG industry because, while oil is considered as an unsustainable business, the revenue it generates is substantially larger than any other industry [23]. However, sustainable business is given a higher reputation among civil society, but might not be given confidence in the stock markets. Thus, with its current investment shift toward renewable energy (RE), the sector presents an ideal setting for an industry under institutional change.

Agreeing that RE activities are outside the core business of OG companies requires these companies to enhance their capabilities of integrating RE knowledge and competencies outside their boundaries. Thus, a sustainable transition in this study is seen as an institutional change that is taking place in an established company and requires more work on legitimacy. We therefore contribute to existing research by employing a quantitative empirical approach and thus developing a measurement system (through a questionnaire) for how the idea of legitimacy is reviewed and measures are derived. The questionnaire is then tested, followed by the results and discussion. Finally, implications, limitations, and directions for future research are provided. However, for the theoretical background of our study, we combine insights from the literature on institutional theory which will be presented next.

\section{Theoretical Aspects}

The Paris Agreement establishes a global goal on a sustainable low carbon future that includes commitments from countries to cut their climate pollution [24]. The EU adopted this agreement and set up policies that aimed to reduce greenhouse gas emissions by $40 \%$ by 2030 ; this has forced EU countries, companies, and society at large to take action and accelerate the achievement of a sustainable low carbon future [25]. This has further forced OG companies to support the Paris Agreement and invest heavily in RE activities [26,27]. 
Thus, by providing a three-dimensional institutional profile, we clarify the distinct roles that the regulatory, normative, and cognitive dimensions play in an OG company; mainly, the roles that lead to the acceptance of sustainable practices in an OG company. This section provides us with an introduction to institutional theory and its evolution. It then describes the three institutional dimensions followed by Scott $[28,29]$ and develops four hypotheses that will be empirically tested later in the study.

\subsection{Legitimacy as A Catalyst for Sustainability}

Ideas and innovation have been studied extensively in the literature; mainly how new ideas are diffused and interpreted in organizations [30,31]. On one hand, the explanation of how new ideas are diffused leans on the economic theory of efficiency. On the other hand, it is more closely associated with a sociological perspective and a focus on the social embeddedness of actors. The sociological perspective leans on the importance of legitimacy for adopting new ideas [32].

This shows that the adoption of the concept of sustainability can be viewed as the diffusion of a new idea. This paper develops a model of an OG company profile by applying the three institutional pillars by Scott [28], and measures the factors that lead an OG company to legitimize new sustainable activities (RE operations in our case). Accordingly, Scott's institutional context has been applied in the literature. For example, the concept of a three-dimensional country institutional profile has been used to explain how a country's government policies (constituting a regulatory dimension), widely shared social knowledge (a cognitive dimension), and value systems (a normative dimension) affect domestic business activity, as developed by Busenitz, et al. [33].

Moreover, another version was later adapted and tested concerning employees' behavior toward innovation [34]. In addition, Oftedal [35] confirmed that the institutional pillars framework measures how a certain concept such as entrepreneurship is legitimized among a specific group. This illustrates that these measurements show different types of legitimacy in different contexts. Finally, Oftedal, et al. [36] developed a new version of the institutional pillars in order to test the legitimacy of student entrepreneurship in universities. As a result, one can conclude that legitimacy has long been viewed as a catalyst for innovation diffusion [37,38], and we believe that it is well-applied in this study.

The three institutional dimensions exist independently of each other in certain societal constructs. For example, while the regulative dimension might favor one certain activity, the normative dimension might favor another. Therefore, it might be difficult to see a real sustainable change within the company despite the fact that they have improved the company's overall strategy. This is also considered as an issue in a company where resistance to a sustainable change would be a large topic in the company.

Furthermore, Suddaby [39] indicates that individuals in any institutional work play an important role in the company; however, their role is almost missing in institutional research. Thus, there is a lack of analysis on an individual's behavior, especially when the change is outside the organizational context [40]. Therefore, our study aims to contribute to institutional research by understanding how new sustainable changes are understood and accepted at the individual level (employees) of an OG company. The next section shows how we applied the theoretical concept of institutional theory to reflect upon an OG company's shift toward RE activities.

\subsection{Model and Hypotheses}

A company is seen as a society in miniature, which shows a culture made up of internal rules, norms, and beliefs in order to guide day to day behavior [41]. New institutionalism has developed a sociological view of institutions in order to explain why and how an institution emerges in a certain way and shapes the behavior of its employees [42]. This approach focuses on the micro level of an institution and enhances new institutional economics with political outcomes [42]. However, Scott [43] made a decisive contribution in adapting the new institutionalism by combining the regulative, normative, and cognitive processes together. 
In addition, Scott [44] believes that the concept of institution and institutionalization can be defined in different ways. Scott [44] argues that some versions are much more explicit and clearer than others and include some similarity and little agreement on the definition [44]. Selznick [45] was one of the earliest and most essential versions of institutional theory, shaping organizational structure in reaction to the commitments of participants and influences from external parties. Thus, Selznick ([45], p.16) clearly views institutionalization as a "process", as something "that happens to the organization over time".

Thus, this paper uses institutional theory, which provides deeper and more resilient aspects of social structure, that enables us to understand how an OG company legitimizes a sustainable transition internally. We thus adopted the institutional theory approach by Drori and Honig [17], which views internal legitimacy as "the acceptance or normative validation of an organizational strategy through the consensus of its participants, which acts as a tool that reinforces organizational practices and mobilizes organizational members around a common ethical, strategic or ideological vision". This view of internal legitimacy explains how the three pillars shape the culture of an organization [17]. It also shows whether the acceptance of an emergent practice takes a 'bottom up' approach where employees at different levels of the resource shape the culture of the organization [46], or when the acceptance takes a more 'top down' approach, where managers/founders shape the organizational culture [47]. Thus, focusing on internal legitimacy plays an essential role in framing organizational identity in order to shape its new strategic direction [17].

This study looks at some of the elements that we have developed to understand what occurs in an OG company in transition; Figure 1 shows an illustration of the developed theoretical framework. Our study, thus, focuses on the development of an appropriate measurement instrument, testing its validity, reliability, and hypotheses through an empirical study.

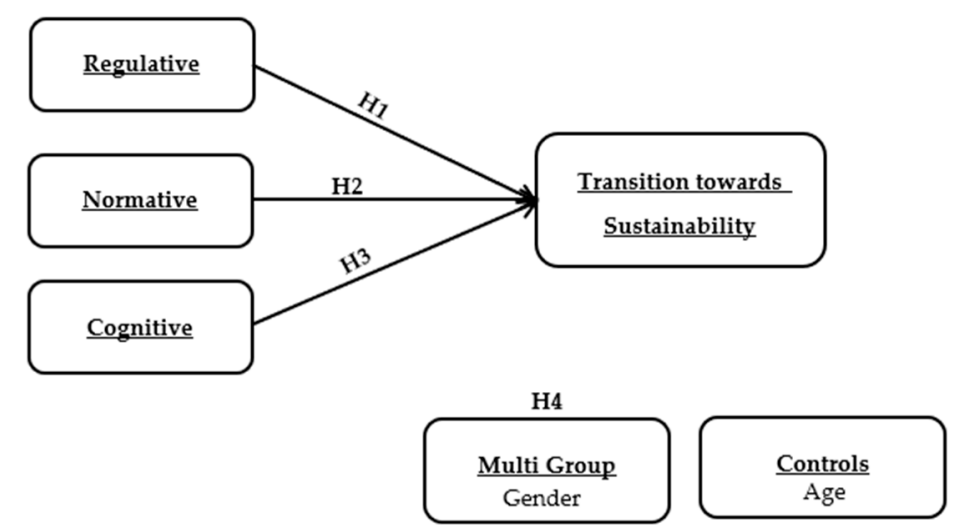

Figure 1. Theoretical framework.

Accordingly, the dependent variable in this study (transition toward sustainability) consists of elements that aim to shift the company toward sustainability. The independent variables include the three institutional pillars. Thus, this study analyzes the relationship (correlation) between sustainable transition and the three institutional pillars by hypothesizing the factor(s) that play(s) a crucial role in legitimizing a company's transition toward sustainability.

Thus, transition toward sustainability is acknowledged as long-term development goals that deal with collective or social interests through new technologies and under supportive policies [48]. The sustainable transition in this study is seen as a sustainable energy or a new shift toward a low-carbon economy. In other words, the establishment of RE activities in an OG company is seen as the main sustainable transition to a clean energy future.

According to the three institutional pillars, first, the regulative view of the institutional profile consists of rules and laws regulated by governments or other authorities that force companies to act in a certain way or provide support for new businesses $[28,49,50]$. Regulative legitimacy is seen as a 
self-evaluation process that enables an organization to map out its activities in order to achieve societal welfare [51].

Second, the normative view of the institutional profile involves values and norms regulated by individuals who introduce, evaluate, select, and implement the organization's new actions [52,53]. Normative legitimacy is seen as a 'self-interested' assessment that enables the individuals to accept its activities based on tangible outcomes of the value they receive [54].

Finally, the cognitive view of an institution deals with the company's assumptions that determine its beliefs and interpretations in a wider belief system and cultural frame [29,53,55]. Cognitive legitimacy is seen as an evaluation or judgement that is required to assess regulative and normative legitimacy [51].

However, in order to fill the lack of research on the company's legitimation strategies, we identified the three pillars in this study as represented in Table 1. First, the regulative pillar deals with the new policies driven by the management team that aim to face the external pressures by governments and other authorities such as the Paris Agreement. Thus, the regulative pillar focuses on the internal policies and strategies initiated by the management team. We thus hypothesize that:

Hypothesis 1. The regulative pillar has a positive effect on transition toward sustainability.

Second, the normative pillar focuses on the employees and their understanding of the value they receive from the new sustainable activities shift that is taking place in the company. Thus, the normative pillar measures the employees' attitudes and their understanding of the sustainable development process. We thus hypothesize that:

Hypothesis 2. The normative pillar has a positive effect on transition toward sustainability.

Third, the cognitive pillar focuses on the company's beliefs that lead to acceptance of its sustainable shift in a wider range of systems and then captures the perception of 'taken-for-grantedness'. We thus hypothesize that:

Hypothesis 3. The cognitive pillar has a positive effect on transition toward sustainability.

In addition, we are interested to know if gender differences matter in sustainable transition. Based on Outsios [56], Polk [57] claims that women are more willing to adopt sustainable actions than men. We thus hypothesize that:

Hypothesis 4. The positive effect of the three institutional pillars on sustainable transition is stronger for females than for males.

Table 1. Dimensions of institutional theory.

\begin{tabular}{|c|c|c|c|}
\hline Construct & Regulative & Normative & Cognitive \\
\hline $\begin{array}{l}\text { Definition adapted } \\
\text { from }[58,59]\end{array}$ & $\begin{array}{l}\text { Formal rules, laws, incentives, } \\
\text { governance system, protocols, } \\
\text { standards and procedures. }\end{array}$ & $\begin{array}{l}\text { Societal expectations, values, } \\
\text { norms and duties. }\end{array}$ & Beliefs, bodies of knowledge. \\
\hline Paradigm for change & $\begin{array}{l}\text { Polices to } \\
\text { enhance sustainability. } \\
\text { - Clear goal } \\
\text { to sustainability. }\end{array}$ & $\begin{array}{l}\text { - Attitudes among } \\
\text { employees that influence } \\
\text { the adoption of } \\
\text { sustainable activities. } \\
\text { - } \quad \text { Sustainability is seen as } \\
\text { a goal. } \\
\text { - Sustainable initiatives } \\
\text { and contributions. }\end{array}$ & $\begin{array}{l}\text { - Sustainability knowledge } \\
\text { and competence among } \\
\text { employees are perceived } \\
\text { as accepted in } \\
\text { the company. } \\
\text { - Good understanding of } \\
\text { sustainability and new } \\
\text { sustainable technologies. }\end{array}$ \\
\hline
\end{tabular}


Table 1. Cont.

\begin{tabular}{|c|c|c|c|}
\hline Construct & Regulative & Normative & Cognitive \\
\hline Motivation for change & $\begin{array}{l}\text { - } \quad \text { Support from the } \\
\text { management team. } \\
\text { Incentives and sanctions } \\
\text { that promote } \\
\text { sustainable activities. }\end{array}$ & $\begin{array}{l}\text { Sustainability is seen as a } \\
\text { future opportunity. }\end{array}$ & $\begin{array}{l}\text { Looking for ways to improve } \\
\text { sustainability. }\end{array}$ \\
\hline Obstacle to change & No incentives. & $\begin{array}{l}\text { No personal responsibility } \\
\text { towards the environment and } \\
\text { society. }\end{array}$ & $\begin{array}{l}\text { No ability to build knowledge } \\
\text { on future sustainable projects. }\end{array}$ \\
\hline
\end{tabular}

\section{Research Method}

This paper employed a quantitative analysis stemming from a survey conducted between 2017-2019 in one of the leading OG companies in Europe. This section explains the empirical context of our study and describes and analyzes the dataset. It also validates the model fit of the study and tests the developed hypotheses that explain how internal legitimacy for new sustainable activities is built in an OG company.

\subsection{Oil and Gas Industry toward Renewable Energy}

Europe's growth strategy aims to reduce greenhouse emissions by $20 \%$ where RE is expected to provide $27 \%$ of the total energy production by 2030 [60]. Wilks [61] confirms that the RE sector is growing fast, and that the OG industry should play a serious role in developing RE activities. This requires large greenhouse emissions producers such as the OG field to enter the RE market.

This paper presents a European OG company committed to providing the world's energy needs in a responsible manner. The company's petroleum activities are crucial for its country's financial growth. In addition, sustainability is already part of the company's overall strategy and they work continuously to reduce their emissions when producing OG. However, the increasing need for energy and a low carbon future is being recognized faster than ever before. In addition to the external pressures to reduce the climate change effects of greenhouse gases [62,63], this has forced the company to be part of the low carbon transformation and introduce an alternative clean energy such as RE.

Thus, the transition toward sustainability is considered new at this company. This means that the company's employees understand the overall sustainability strategy, but this does not guarantee that investing in RE is considered accepted by everyone in the company. This is due to the fact that the development of RE activities by major OG companies requires different corporate strategies that aim to achieve a long-term economic advantages [64]. For this reason, the next sections will empirically show how we measured and validated the model fit of this study.

\subsection{Description of the Dataset}

This study included a Likert scale (ordinal variables) where structural equation modeling (SEM) and Chi-square test statistics are a key diagnostic to measure the model fit $[65,66]$. SEM is one of the most powerful tools being increasingly used in social sciences to test and evaluate multivariate causal relationships [67]. It was used in this study to check the overall goodness of fit in the model, improve the model fit, and validate the reliability and stability of the model [67]. Thus, SEM is used to explain the relationship between latent variables by one or more observed variable, and to determine how far the theoretical model fits the data [68]. In addition, a good fit of the model is essential for determining whether the conclusions about participants on the scale are valid [69].

Thus, we developed a survey instrument that allowed us to empirically validate a survey that measures the profile of the company's employees as a key driver for legitimizing a sustainable future, as shown in Table 2. This section contains a brief review of our methodological approach, adopted from MacKenzie, et al. [70], as shown in the scale development procedure in Figure 2. In the first step, 
we developed and refined our institutional measures, then we created our survey, pre-tested, and distributed it. These measures were used in the scale evaluation and validation as a second step.

Table 2. Items for measuring the institutional pillars.

\begin{tabular}{|c|c|}
\hline Variables & Items \\
\hline \multirow{5}{*}{ Regulative Pillar } & Your management team supports renewable energy activities \\
\hline & There are incentives for sustainable activities at X Company $* * *$ \\
\hline & X Company has policies to enhance its sustainable development practices ${ }^{* * *}$ \\
\hline & 4. Your management team has clear goals to make $X$ a sustainable company \\
\hline & 5. Top management plays an important role in making $X$ a sustainable company \\
\hline \multirow{5}{*}{ Normative Pillar } & $\begin{array}{l}\text { Employees want to contribute to a variety of sustainable projects in my } \\
\text { unit }\end{array}$ \\
\hline & Individual initiatives towards sustainability are respected in my unit ${ }^{* * *}$ \\
\hline & $\begin{array}{l}\text { 3. Sustainable activities are seen as the way toward future opportunities in my } \\
\text { unit } * * *\end{array}$ \\
\hline & 4. Operating sustainability is a goal in my unit ${ }^{* * *}$ \\
\hline & $\begin{array}{l}\text { 5. In my unit, we believe that we have a personal responsibility/commitment } \\
\text { towards society/the environment }\end{array}$ \\
\hline \multirow{4}{*}{ Cognitive Pillar } & 1. My unit has a good understanding of sustainability ${ }^{* * *}$ \\
\hline & 2. My unit has a good understanding of sustainable technology \\
\hline & 3. My unit builds knowledge on becoming more sustainable ${ }^{* * *}$ \\
\hline & My unit is always looking for additional ways to improve sustainability $* * *$ \\
\hline \multirow{4}{*}{ Transition toward sustainability } & $\begin{array}{l}\text { 1. X Company has established environmental targets to introduce a shift toward } \\
\text { sustainability*** }\end{array}$ \\
\hline & $\begin{array}{l}\text { 2. Sustainability will become considerably more important to X Company in the } \\
\text { future }\end{array}$ \\
\hline & 3. X Company has implemented sustainability goals into their overall strategy \\
\hline & $\begin{array}{l}\text { 4. This is the right time for X Company to introduce clean activities into their } \\
\text { business practices }\end{array}$ \\
\hline
\end{tabular}

Step 1

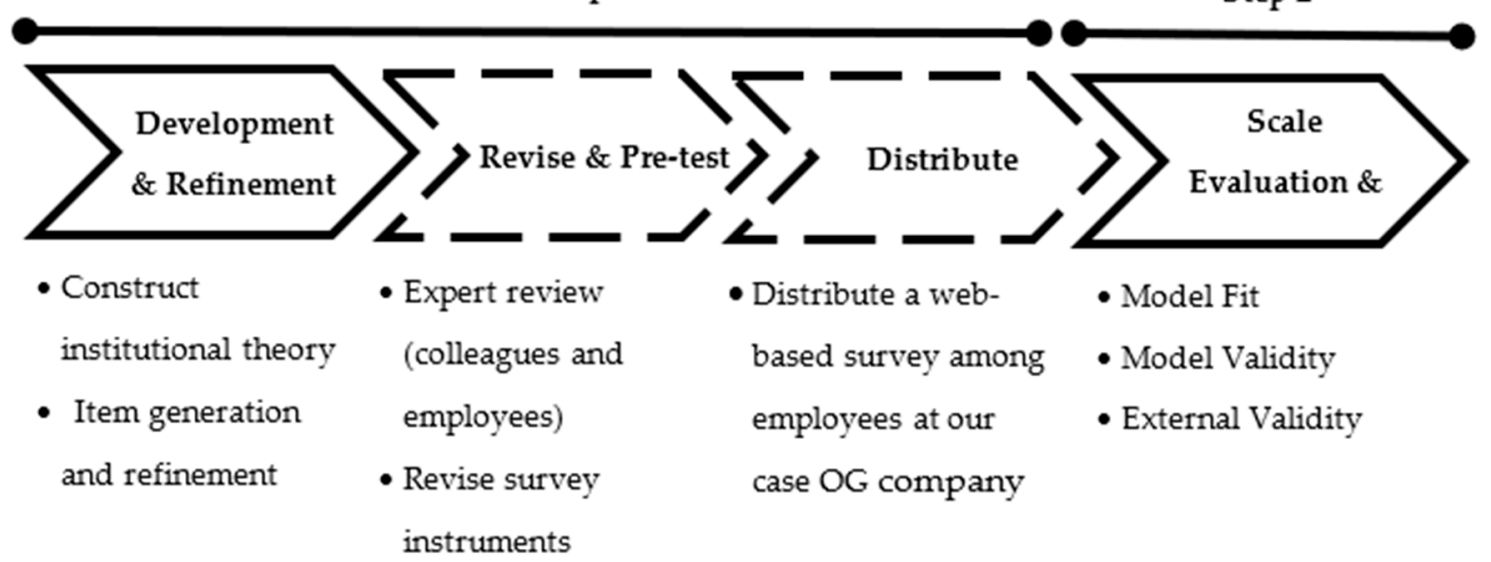

\section{- Pretesting survey}

with employees

Figure 2. Scale development procedure.

\subsection{Step 1: Development and Refinement of Institutional Measures}

Institutional theory is used as a powerful explanation for both individual and organizational action [22]. In this study, we used a specific company as an example for the OG industry in which RE has become institutionalized, focusing our study on a European OG company.

Accordingly, we began operationally developing the institutional profile of our study that is related to sustainable practices. We derived a large pool of items from the institutional literature, particularly from the three pillars of institutions by Scott $[29,43]$, as shown in Table 2, which indicates 
the items relevant to our research question and were used in this study [71]. For the regulatory pillar, five items were generated that focused on management policies supporting new sustainable businesses (renewable energy), the management role in making a sustainable company, and indirect government support for OG companies that came through incentives. The intent of the regulatory pillar was to measure the institutional arrangements that would affect an OG company's business agenda as a whole.

The normative pillar consisted of five items focusing on employees' contributions to sustainable activities and their sustainable goals and personal responsibility toward society and the environment. The purpose of the normative pillar was to measure the employees' engagement in the company's sustainable shift. Finally, the cognitive pillar included four items with the aim to accelerate the company's awareness of sustainability, enhance sustainable knowledge, and thus promote sustainable development. The aim of the cognitive pillar was to measure sustainability awareness in the company that will more likely help manage new sustainable activities.

In addition, our dependent variable (transition toward sustainability) included four items as described in Table 2 that focused on the employees' perception of the new sustainable transition that is taking place in the company. This includes environmental goals and targets that will make the company more sustainable.

By following the methodological approach suggested by MacKenzie, Podsakoff and Podsakoff [70], we first developed conceptual definitions for the three institutional pillars related to the introduction of RE activities in an OG company. We then developed a web-based survey and conducted several pre-test rounds with twelve experts; six academic experts and six employees from our case company. They reviewed the original survey and helped shape the content and form a survey that resulted in better data quality. Our survey used a seven-point Likert scale because it works better with educated samples [72]. The data to evaluate the model were gathered among employees from a European OG company in the period between 2017 and 2019.

\section{Data Analysis and Results}

Our case company is a broad energy company that involves thousands of employees. However, due to its high policy, the company allowed us to collect the data by distributing our survey through our contact person via the company's internal network. Therefore, our data included only the participants who voluntarily filled out our survey, resulting in a dataset of 113 respondents.

After undertaking data screening, we excluded 21 respondents who had missing values, in addition to one unengaged respondent who gave the exact same response for every single item. We had also three variables with missing values, all less than $5 \%$ missing, which we replaced with the mean. This left us with a dataset of 91 responses. In addition, we intended to do a skewness and kurtosis variable screening test to find if there were any abnormal variables. We found two abnormal variables: regulative (item 5) and transition toward sustainability (item 4).

Exploratory factor analysis (EFA) was used to regroup our variables into a limited set of items so that relationships and patterns between variables could be easily interpreted and understood [73]. In addition, maximum likelihood and ProMax rotation were selected and used to estimate the factor loadings and because it is more useful when undertaking confirmatory factor analysis (CFA) in statistical Software Analysis of Moment Structures (AMOS) [74]. When applying the EFA, a decision was made to drop the abnormal items (regulative 5 and transition toward sustainability 4 ). Then, we forced the factors to extract four factors and dropped the problematic items one by one respectively; cognitive 2 , normative 5 , transition 3 , regulative 4 , and regulative 1 . The final pattern matrix table is displayed in Table 3. Table 3 contains the rotated factor loadings that shows how the variables were loaded significantly on each factor and represents the correlation between the variables and the factors. The four-factor solution provided meaningful factors that reflected regulatory, normative, and cognitive pillars and transition toward sustainability, explaining $73.67 \%$ of the variance. The Kaiser-Meyer-Olkin (KMO) test was 0.87 and the Bartlett's test was significant. However, Cronbach's alphas confirmed 
an internal-consistency coefficient for the regulatory pillar (0.88), normative pillar (0.87), cognitive pillar (0.93), and transition toward sustainability (0.69). Thus, the final survey instrument consisted of 11 items: two items for the regulative pillar, four for the normative pillar, three for the cognitive pillar, and two items for the transition toward sustainability as shown in Table 2 (text displayed in ${ }^{* * *}$ ).

Table 3. Pattern matrix ${ }^{\mathrm{a}}$.

\begin{tabular}{lcccc}
\hline & \multicolumn{5}{c}{ Factor } \\
\cline { 2 - 5 } & $\mathbf{1}$ & $\mathbf{2}$ & $\mathbf{3}$ & $\mathbf{4}$ \\
\hline Cronbach's Alpha & 0.932 & 0.873 & 0.876 & 0.69 \\
Regulative Pillar 2 & & & 0.775 & \\
Regulative Pillar 3 & & & 0.989 & \\
Normative Pillar 1 & & 0.541 & & \\
Normative Pillar 2 & & 0.613 & & \\
Normative Pillar 3 & & 0.997 & & \\
Normative Pillar 4 & & 0.726 & & \\
Cognitive Pillar 1 & 0.647 & & & 0.871 \\
Cognitive Pillar 3 & 0.955 & & & 0.567 \\
Cognitive Pillar 4 & 0.920 & & & \\
Transition 1 & & & & \\
Transition 2 & & & & \\
\hline
\end{tabular}

Extraction method: Maximum likelihood. Rotation method: Promax with Kaiser normalization. ${ }^{a}$ Rotation converged in five iterations.

\subsection{Step 2: Scale Evaluation and Validation}

In our study, we chose to validate the survey instrument with employees in different positions in the OG company. The survey was distributed mainly to people who had a deeper knowledge of relevant sustainability business issues than the rest of the company. The survey was administered to employees who faced major sustainability changes and invested heavily in RE activities as a step to move from an OG into a broad energy company. In addition, our case company engaged its employees in its sustainable activities in order to meet its new challenges, which makes the three institutional pillars relevant in this paper. The survey was conducted in two languages, English and the local nation language of the country where the company is located. Of the respondents, 71 filled out the survey online and 20 respondents filled out a paper-based survey. Most respondents (43\%) were between 41 and 55 years old and (37\%) were between 26 and 40 years old. Slightly more than half of the sample's members were men $(52 \%)$.

\subsubsection{Model Fit}

We used SEM to perform a CFA on the company institutional profile measure. CFA was used to verify the factor structure that was extracted from the EFA [75]. However, since we are in the early stages of developing our model, we applied a common method bias (CMB) that will allow us to test the fit of the model by using a common latent factor (CLF) against the alternative one without the CLF [76]. We first ran the CFA on the reduced model (11 items) and measured the correlations among the latent variables. We had to drop one item (normative 1) due to low loadings between factors. We then ran the $\mathrm{CMB}$ and compared the unconstrained common method factor model to the fully zero constrained common factor model. The Chi-square test by Gaskin [77] showed a significant $p$-value as shown in Table 4. 
Table 4. Common bias method test results.

\begin{tabular}{|c|c|c|c|c|c|}
\hline & Chi-Square & $\mathrm{df}$ & $p$-Value & Invariant? & \\
\hline $\begin{array}{l}\text { Overall Model } \\
\text { Unconstrained } \\
\text { Fully constrained } \\
\text { Number of groups }\end{array}$ & $\begin{array}{l}21.4 \\
56.9\end{array}$ & $\begin{array}{c}19 \\
29 \\
2\end{array}$ & & & $\begin{array}{l}\text { Step 1. Provide Chi-square and df for } \\
\text { unconstrained and constrained models, } \\
\text { and provide the number of groups. The } \\
\text { thresholds will be updated automatically. }\end{array}$ \\
\hline Difference & 35.5 & 10 & 0.000 & $\mathrm{NO}$ & $\begin{array}{l}\text { Groups are different at the model level. } \\
\text { Check path differences. }\end{array}$ \\
\hline
\end{tabular}

The result provided evidence of a problem in the fully constrained model (CFI =0.96, RMSEA $=0.10$, GFI $=0.89$, and PCLOSE $=0.019$ ), which led us to retain the actual model with the CLF as shown in Figure 3. In other words, the model with the CLF method showed a better model fit (CFI = 0.997, RMSEA $=0.037, \mathrm{GFI}=0.995$, and PCLOSE $=0.563$ ).

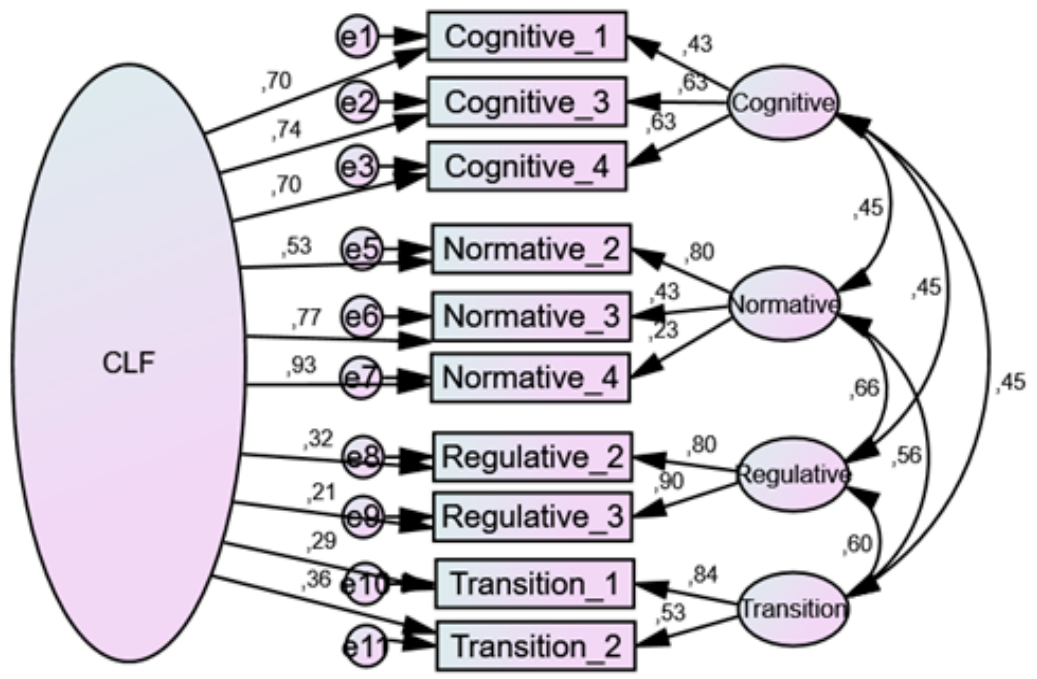

Figure 3. Confirmatory factor analysis results (unconstrained model where all paths are constrained to zero).

Our assumptions was based on Hair, et al. [78], who defined the comparative fit index (CFI) as an incremental fit index, and is accepted when the values are between 0 and 1 ; the higher value indicates a better fit. Root mean square error of approximation (RMSEA) represents how well a model fits a population, and it is accepted when the value is between 0.03 and 0.08 . Goodness of fit index (GFI) is a fit statistic that is less sensitive to sample size, and the possible range of GFI is 0 to 1 where a higher value indicates a better fit. However, according to Kenny, et al. [79], a fit indices in confirmatory factor analysis (PCLOSE) measures the fit indices in CFA and helps understand the sampling error in the RMSEA. It is normally used for small DF and low N models, and is accepted when it is greater than 0.05 .

The shortened scale, with three cognitive, three normative, two regulatory, and two sustainability toward transitions items was retained. Thus, the CFA was performed on the 91 responses by adding the CLF in order to capture the common variance among all observed variables in the model.

However, in order to examine which items contributed to a sustainable transition in an OG company, multiple regression analysis was run by Statistical Package for Social Sciences (SPSS) software. The general model takes the following equation:

$$
\mathrm{Y}=\beta_{0}+\beta_{1} * \text { Reg. }+\beta_{2} * \text { Norm. }+\beta_{3} * \operatorname{Cog}+\varepsilon
$$

where $Y$ refers to the dependent variable (transition toward sustainability) and represents transition 1 and transition 2; Reg. represents regulative 2 and regulative 3; Norm represents normative 2, 3, and 
4; and Cog. represents cognitive 1, 3, and 4 . In addition, $\beta_{0}$ represents constants; $\beta_{i}$ represents the unstandardized coefficients for each independent variable (derived from Table 5); and $\varepsilon$ represents the error term. After doing the analysis, the equation takes the form:

Transition toward sustainability $=2.14+0.34{ }^{*}$ Reg. $+0.26{ }^{*}$ Norm. $+0.17{ }^{*}$ Cog. $+\varepsilon$

Table 5. Coefficients ${ }^{a}$.

\begin{tabular}{clccccccc}
\hline \multirow{2}{*}{ Model } & \multicolumn{2}{c}{$\begin{array}{c}\text { Unstandardized } \\
\text { Coefficients }\end{array}$} & \multicolumn{2}{c}{$\begin{array}{c}\text { Standardized } \\
\text { Coefficients }\end{array}$} & & \multicolumn{2}{c}{$\begin{array}{c}\text { Collinearity } \\
\text { Statistics }\end{array}$} \\
\cline { 3 - 9 } & & B & Std. Error & Beta & $\mathbf{t}$ & Sig. & Tolerance & VIF \\
\hline \multirow{2}{*}{1} & (Constant) & 2.135 & 0.303 & & 7.041 & 0.000 & & \\
& Regulative & 0.342 & 0.104 & 0.377 & 3.301 & 0.001 & 0.481 & 2.081 \\
& Normative & 0.264 & 0.099 & 0.303 & 2.671 & 0.009 & 0.488 & 2.049 \\
& Cognitive & 0.169 & 0.148 & 0.101 & 1.145 & 0.256 & 0.811 & 1.234 \\
\hline
\end{tabular}

${ }^{\mathrm{a}}$ Dependent variable: Transition.

\subsubsection{Model Validity}

\section{External Validation}

Another objective of this study was to validate a measure of the company institutional profile. Thus, it required some comprehensive validity assessments to ascertain the utility of this measure [80]. Therefore, the goal of testing a SEM is measuring concepts in a reliable and valid manner [78]. In this section, we aimed to test how well the variables related to one another by measuring reliability, convergent validity, and discriminant validity. Thus, by using a formula provided by Gaskin [77], as presented in Table 6, we automatically calculated the construct reliability (CR), average variance extracted (AVE), and maximum shared variance (MSV).

Table 6. Reliability and validity results ${ }^{1}$.

\begin{tabular}{lcccccccc}
\hline & CR & AVE & MSV & MaxR (H) & Regulative & Cognitive & Normative & Transition \\
\hline Regulative & 0.881 & 0.787 & 0.461 & 0.882 & 0.887 & & & \\
Cognitive & 0.935 & 0.829 & 0.677 & 0.963 & 0.524 & 0.910 & & \\
Normative & 0.904 & 0.759 & 0.677 & 0.914 & 0.587 & 0.823 & 0.871 & \\
Transition & 0.714 & 0.556 & 0.461 & 0.724 & 0.679 & 0.603 & 0.589 & 0.746 \\
\hline
\end{tabular}

${ }^{1} \mathrm{CR}$ measures the internal consistency of the variables and is accepted when it is 0.7 or higher. AVE (convergent validity) assesses the degree of correlation between two variables of the same concept, and is accepted when it is higher than 0.5. MSV (discriminant validity) measures the extent to which a construct is truly distinct from another, and it should be less than the AVE [78].

\section{Construct Reliability (CR)}

We assessed the CR of each pillar of our institutional profile, as shown in Table 6, and found that all of the measures met the threshold suggested by Hair, Black, Babin and Anderson [78] (CR > 0.7). Thus, the scales show an excellent reliability for the three institutional pillars. In sum, the scales underlying our company institutional profile showed very good internal consistency.

\section{Convergent Validity (AVE)}

We measured the convergent validity of each institutional pillar as shown in Table 6 . This is essential in the SEM in order to understand which pillars share a high proportion of variance in common. We found that all of the measures met the threshold suggested by Hair, Black, Babin and Anderson [78] (AVE > 0.5). We also compared our measures to a survey question contained in a publication of the international conference on information system [40]. The mentioned study 
asked actors to rate their institutional influences on adopting green innovations that were outside the organizational context on a five-point Likert scale. We found that our regulatory pillar (0.79) correlated positively $(\mathrm{P}<0.03)$ to their regulatory pillar $(0.82)$. In addition, our cognitive pillar $(0.94)$ correlated positively $(\mathrm{P}>0.26)$ to their cognitive pillar $(0.68)$. However, our normative pillar $(0.56)$ correlated positively $(\mathrm{P}<0.09)$ to their normative pillar $(0.65)$. In sum, these comparisons indicate a respectable correspondence between our measures of the regulatory, cognitive, and normative pillars and relevant variables from external sources.

\section{Discriminant Validity (MSV)}

We measured discriminant validity in order to understand the difference between these pillars and the phenomena they capture. This is essential in order to know if one measure (institutional pillar in our case) is distinct from another measure [78,80]. The results from Table 6 show that the discriminant validity (MSV) is supported in the three pillars (regulatory, normative, and cognitive) (MSV < AVE). This means that the three institutional pillars influence internal employees to legitimize sustainable changes, and attempt to start or manage sustainable activities in the company. The next section will show how we tested our hypotheses, and which pillar will take a stronger role to build internal legitimacy.

\subsection{Testing Hypotheses}

In order to test our hypotheses, we imputed the factor scores for our variables and looked at the influential records in the dataset by using Cook's distance analysis, which found one record with an abnormal Cook's distance. We decided to remove it from our data in order to strengthen the regression weight, which we will later observe in our results. Furthermore, we performed a multicollinearity test in order to predict the correlation between the independent variables themselves and with the dependent variables. Therefore, we intended to test the tolerance that measures unexplained independent variables by other independent variables in the model, and it should be greater than $0.1[78,81,82]$. In addition, we tested the variance inflation factor (VIF) that translates the tolerance value in order to express the degree of multicollinearity, and it should be less than $3[78,81,82]$. Thus, results presented in Table 5 shows that we did not have any multicollinearity problems (tolerance $>$ $0.1, \mathrm{VIF}<3)$.

As a result, our new causal model was built by AMOS and left us with a good model fit (CFI $=0.999$, GFI $=0.992$, PCLOSE $=0.413$, and RMSEA $=0.032$ ). This also shows that our model explains $46 \%$ of the outcome data $\left(R^{2}=0.46\right)$. In addition, Table 7 shows the regression weights for our model and indicates that $\mathrm{H} 1$ (regulative pillar) and $\mathrm{H} 2$ (normative pillar) have significant and positive effects on sustainable transition.

Table 7. Regression weights ${ }^{b}$.

\begin{tabular}{llllccc}
\hline & & & Estimate & S.E. & C.R. & P \\
\hline Transition & $<-$ & Regulative & 0.342 & 0.102 & 3.358 & ${ }^{* * *}$ \\
Transition & $<-$ & Normative & 0.264 & 0.097 & 2.717 & $0.007^{* *}$ \\
Transition & $<-$ & Cognitive & 0.169 & 0.145 & 1.164 & 0.244 \\
\hline \multicolumn{6}{c}{${ }^{*}{ }^{* * *} P<0.001,{ }^{* *} P<0.01}$.
\end{tabular}

However, in order to test $\mathrm{H} 4$, we undertook a Chi-square difference test for the whole model, as shown in Table 8 [77]. We found that the Chi-square difference test was not significant $(P=0.228)$, indicating that the effect was not different for males than females. We then measured the Chi-square for each single path (regulative, normative, and cognitive) and found a non-significant $P$ value for each path of $0.206,0.274$, and 0.183 , respectively. As a result, we concluded that $\mathrm{H} 4$ is not supported, meaning that the measures are the same across groups and between paths. 
Table 8. Chi-square test across two groups (female/male).

\begin{tabular}{|c|c|c|c|c|c|}
\hline & Chi-Square & $\mathrm{df}$ & $p$-Value & Invariant? & \\
\hline $\begin{array}{l}\text { Overall Model } \\
\text { Unconstrained } \\
\text { Fully constrained } \\
\text { Number of groups }\end{array}$ & $\begin{array}{l}100.4 \\
115.9\end{array}$ & $\begin{array}{c}58 \\
68 \\
2\end{array}$ & & & $\begin{array}{l}\text { Step 1. Provide Chi-square and df for } \\
\text { unconstrained and constrained models, } \\
\text { and provide the number of groups. The } \\
\text { thresholds will be updated automatically. }\end{array}$ \\
\hline Difference & 3.763 & 3 & 0.228 & YES & $\begin{array}{l}\text { Groups are not different at the model level, } \\
\text { however, they may be different at the } \\
\text { path level. }\end{array}$ \\
\hline
\end{tabular}

Finally, a post-hoc analysis was tested to make sure that our non-significant effect on gender and cognitive legitimacy was truly not significant. Post hoc test is required when a hypothesis is not supported, and it should be greater than $0.8[78,83]$. Our post-hoc result gave us a value of 1 , meaning that our non-significant effect was valid.

\section{Discussion}

Measuring sustainability is seen as a challenging task since it is difficult to implement and there is no specific goal to obtain when introducing sustainability within companies $[13,14,51]$. Therefore, we found it interesting to measure legitimacy among employees in an OG company, because they shape their legitimacy based on their experience within the company [51]. This enabled us to understand how employees direct actions, practices, and values and understand how they translate these actions into a benefit for their organization [17].

Our findings offer interesting insights into the literature on institutional theory and contribute to a richer understanding of internal legitimacy. Other studies have focused on the emergence of new institutional practices [84,85], the evolution of new institutions [86,87], or the role of individuals in embracing or undermining new practices [46].

The institutional theory presented here draws attention to how an established company under a sustainable change builds its internal legitimacy. The developed model is built around the three institutional pillars and sustainability and aims to analyze the employees' role in shifting an established OG company to a broad energy company. Based on the model, our key findings reveal that our case company employed regulative and normative legitimacy to justify their transition toward RE activities.

Our findings present regulative legitimacy as the important carrier of shaping the sustainable transition in the company. The company's employees consider their management team as the initial supporter for sustainability. This shows that the management team is responsible for adopting sustainable commitments and establishing new policies that aim to enhance the sustainable development practices in the company. At the same time, our results show that normative legitimacy plays an important role in strengthening the sustainability transition. This shows that the employees have a self-interest to shift the company toward a sustainable future and that they see sustainability as the way toward future opportunities. However, cognitive legitimacy was not supported in this study. Cognitive legitimacy requires more time in order to be achieved so that everybody in the company understands and accepts the sustainable shift that is taking place in the company.

Thus, our study shows that the company's employees understand the environmental issues and the sustainable development change that is taking place in the world. They also believe that OG companies should change in order to help the environment, accelerate the transition toward clean energy, and cover that need in the market. This emphasizes that the change must be achieved internally in order to enhance the actual shift toward sustainability afterward.

We empirically explored the rhetorical justification for investments in new sustainable technologies, and found significant support in both regulative and normative legitimacy. Our findings support previous work by Drori and Honig [17], who argued that regulative and normative legitimacy play an essential role in framing organizational identity and shaping its strategic direction. In addition, Laïfi and Josserand [88] argued that gaining cognitive legitimacy would be automatically achieved when 
regulative and normative are legitimized in companies and should be adopted on a large scale when the new change becomes taken-for-granted.

These results are expected for a company under sustainable change for several reasons: (1) People see that a large OG producer such as our case company should focus on producing OG that gives the company the most profitable business; (2) people consider that there is still a market demand for OG even if RE is growing very fast; and (3) some see that investing in RE is a risky business for an OG company since it is outside the core business and requires new skills, competencies, and technologies.

In line with our argument above on regulative and normative legitimacy as a carrier of sustainable change, previous research shows that commitment leads to the adoption of responsibility standards [89]. In our study, we argue that new policies, new sustainable strategies, and self-interest can accelerate the institutionalization of sustainability in an OG company. This complements previous studies that have identified regulative and normative legitimacy as contributors.

Additionally, we observed that gender has no effect on legitimizing new sustainable practices. This is surprising, given the previous research suggesting that women are more willing to adopt sustainable action $[56,57]$. However, we believe that sustainability is becoming essential in companies that are striving to adopt sustainability in their organizational culture.

Our contribution to the literature is based on an OG company under sustainable change; a situation where the company has to legitimize its investments in RE practices. This is essential in order for an OG company to meet its internal uncertainties, especially when it is investing in new technologies that are outside its core business. We propose that regulative and normative legitimacy are a potential indicator of institutional change in an OG company and a carrier of a new sustainable process. We thus indicate that the OG sector is at a crossroads of intersecting legitimacy for the new sustainable technologies populating it.

\section{Conclusions, Limitations, and Future Studies}

Our study aimed to make a methodological contribution to the research of legitimacy by developing a valid measure of regulative, normative, and cognitive legitimacy. In this study, we developed and empirically validated a survey instrument for measuring the institutional profile of an OG company under a sustainable transition. This study showed us a 'top-down' approach where the regulative pillar plays the essential role in legitimizing the investment of sustainable activities in an OG company. The normative pillar also plays an important role in legitimizing the company's investment of sustainable activities. More information about our results is summarized in Appendix A.

This study contributes to the broader literature on legitimacy by developing a measure of all three institutional pillars of legitimacy that can be adapted for different research contexts. Thus, our study makes two contributions. First, our company institutional profile can serve as a tool to understand employees' acceptance of the new sustainable transition that is taking place in the company. Second, the study helps researchers and companies understand the relevance of the three pillars and the role they play in adopting new activities. This is important for companies to improve their institutional environment for sustainability.

We believe that our instrument was conceived as an initial measure of a company institutional profile for legitimizing sustainability. Our sample represents a specific example of a European OG company. Additional studies in other cultures, companies, industries, and research contexts would help generalize our method in the future. This can be done through developing or applying our survey instrument in a broader context and comparing it with other methods. This would show us how other companies would act and which pillar plays the essential role in legitimizing their new investments. Thus, more research on legitimacy as an institutional theory will help us understand the complexity of this phenomenon and enhance our understanding of organizational culture in different industries.

In sum, the scales developed in this study can improve both the empirical and theoretical rigor of legitimacy. The scales underlying our OG company institutional profile have valid reliability, external 
validity, and discriminant validity. Thus, this institutional profile should provide a useful tool with which researchers can explore a variety of issues regarding legitimizing new activities in companies.

\section{Informed Consent}

Informed consent was obtained from all individual participants included in the study.

Author Contributions: Conceptualization, T.J. and E.M.O.; Methodology, T.J.; Software, T.J.; Validation T.J. and E.M.O.; Formal analysis, T.J.; Investigation, T.J. and E.M.O.; Resources, T.J. and E.M.O.; Data curation, T.J.; Writing—original draft preparation, T.J; Writing—review and editing, T.J. and E.M.O.; Visualization, T.J.; Supervision, E.M.O.; Project administration, T.J. and E.M.O.; Funding acquisition, T.J. All authors have read and agreed to the published version of the manuscript.

Funding: The publication charges for this article were funded by a grant from the publication fund of UiT, The Arctic University of Norway.

Acknowledgments: We would like to thank David Gibson, Tatiana Iakovleva, Mikko Moilanen, Martin Shrolec, and Jessica Green for their valuable feedback on the survey. We would also like to thank all the people from our case company for their assistance and time in filling out our survey.

Conflicts of Interest: The authors declare no conflicts of interest

\section{Appendix A Summary of the Analysis of Hypotheses}

\begin{tabular}{|c|c|c|}
\hline Hypothesis & Quantitative Analysis & Comment \\
\hline Hypothesis 1 & Supported & $\begin{array}{l}\text { The positive relationship between regulative pillar and } \\
\text { transition toward sustainability was supported. This } \\
\text { confirms that our case company has new policies and } \\
\text { strategies to invest in RE practices. }\end{array}$ \\
\hline Hypothesis 2 & Supported & $\begin{array}{l}\text { The positive relationship between normative pillar and } \\
\text { transition toward sustainability was supported, but comes } \\
\text { second place after the regulative. This also confirms that } \\
\text { internal employees are engaged and have a self-interest } \\
\text { toward the new sustainable shift in the company. }\end{array}$ \\
\hline Hypothesis 3 & Not Supported & $\begin{array}{l}\text { The relationship between cognitive legitimacy and transition } \\
\text { toward sustainability was not supported. This informs us } \\
\text { that sustainable activities are not fully legitimized in the } \\
\text { company. The sustainable activities have been introduced } \\
\text { recently in the company, and it requires more time to be } \\
\text { accepted by everyone in the company. }\end{array}$ \\
\hline Hypothesis 4 & Not Supported & $\begin{array}{l}\text { The relationship between gender and transition toward } \\
\text { sustainability was not supported in this study. This shows } \\
\text { that there is no gender effect on legitimizing sustainable } \\
\text { activities. This shows that the employees are interested in } \\
\text { making the OG company a cleaner one. }\end{array}$ \\
\hline
\end{tabular}

\section{References}

1. Werbach, A. Strategy for Sustainability: A Business Manifesto; Harvard Business: Boston, MA, USA, 2009.

2. Peng, Y.; Li, J.; Yi, J. International Oil Companies' Low-Carbon Strategies: Confronting the Challenges and Opportunities of Global Energy Transition. IOP Conf. Ser. Earth Environ. Sci. 2019, 237. [CrossRef]

3. Rodrigues, M.; Franco, M. The Corporate Sustainability Strategy in Organisations: A Systematic Review and Future Directions. Sustainability 2019, 11, 6214. [CrossRef]

4. Schrettle, S.; Hinz, A.; Scherrer-Rathje, M.; Friedli, T. Turning sustainability into action: Explaining firms' sustainability efforts and their impact on firm performance. Int. J. Prod. Econ. 2014, 147, 73-84. [CrossRef]

5. Deephouse, D.L.; Suchman, M. Legitimacy in organizational institutionalism. In The Sage Handbook of Organizational Institutionalism; Greenwood, R., Oliver, C., Sahlin, K., Suddaby, R., Eds.; SAGE Publications: London, UK, 2008; pp. 49-77.

6. Galaskiewicz, J. Interorganizational Relations. Annu. Rev. Sociol. 1985, 11, 281-304. [CrossRef] 
7. Hargadon, A.B.; Douglas, Y. When Innovations Meet Institutions: Edison and the Design of the Electric Light. Adm. Sci. Q. 2001, 46, 476-501. [CrossRef]

8. Suchman, M.C. Managing Legitimacy: Strategic and Institutional Approaches. Acad. Manag. Rev. 1995, 20, 571-610. [CrossRef]

9. Engert, S.; Rauter, R.; Baumgartner, R.J. Exploring the integration of corporate sustainability into strategic management: a literature review. J. Clean. Prod. 2016, 112, 2833-2850. [CrossRef]

10. Moldavska, A. Defining Organizational Context for Corporate Sustainability Assessment: Cross-Disciplinary Approach. Sustainability 2017, 9, 2365. [CrossRef]

11. Patala, S.; Korpivaara, I.; Jalkala, A.; Kuitunen, A.; Soppe, B. Legitimacy Under Institutional Change: How incumbents appropriate clean rhetoric for dirty technologies. Organ. Stud. 2019, 40, 395-419. [CrossRef]

12. Gond, J.-P.; Grubnic, S.; Herzig, C.; Moon, J. Configuring management control systems: Theorizing the integration of strategy and sustainability. Manag. Account. Res. 2012, 23, 205-223. [CrossRef]

13. Baumgartner, R.J.; Rauter, R. Strategic perspectives of corporate sustainability management to develop a sustainable organization. J. Clean. Prod. 2017, 140, 81-92. [CrossRef]

14. Sandhawalia, B.S.; Dalcher, D. Dynamic Knowledge Support Model for Decision-Making and Sustainable Growth: An Empirical Study. Group Decis. Negot. 2015, 24, 803-823. [CrossRef]

15. Fisher, G.; Kotha, S.; Lahiri, A. Changing with the times: An integrated view of identity, legitimacy, and new venture life cycles. Acad. Manag. Rev. 2016, 41, 383. [CrossRef]

16. Jawahar, I.M.; McLaughlin, G.L. Toward a Descriptive Stakeholder Theory: An Organizational Life Cycle Approach. Acad. Manag. Rev. 2001, 26, 397-414. [CrossRef]

17. Drori, I.; Honig, B. A Process Model of Internal and External Legitimacy. Organ. Stud. 2013, 34, 345-376. [CrossRef]

18. Dimaggio, P.J.; Powell, W.W. The Iron Cage Revisited: Institutional Isomorphism and Collective Rationality in Organizational Fields. Am. Sociol. Rev. 1983, 48, 147-160. [CrossRef]

19. Greenwood, R.; Suddaby, R.; Hinings, C. Theorizing change: The role of professional associations in the transformation of institutional fields. Acad. Manag. J. 2002, 45, 58-80. [CrossRef]

20. Rocha, R.S.; Granerud, L. The search for legitimacy and organizational change: The agency of subordinated actors. Scand. J. Manag. 2011, 27, 261-272. [CrossRef]

21. Li, J.; Tang, Y. CEO hubris and firm risk taking in China: the moderating role of managerial discretion. Acad. Manag. J. 2010, 53, 45. [CrossRef]

22. Dacin, M.T.; Goodstein, J.; Scott, W.R. Institutional Theory and Institutional Change: Introduction to the Special Research Forum. Acad. Manag. J. 2002, 45, 45-56. [CrossRef]

23. American Petroleum Institute. Putting Earnings into Perspective-Facts for Addressing Energy Policy; American Petroleum Institute: Washington, DC, USA, 2016.

24. United Nations Climate Change. What is the Paris Agreement? Available online: https://unfccc.int/processand-meetings/the-paris-agreement/what-is-the-paris-agreement (accessed on 27 November 2019).

25. European Commission. Paris Agreement. Available online: https://ec.europa.eu/clima/policies/international/ negotiations/paris_en\#tab-0-0 (accessed on 27 February 2019).

26. Hansen, G.H.; Steen, M. Offshore oil and gas firms' involvement in offshore wind: Technological frames and undercurrents. Environ. Innov. Soc. Transit. 2015, 17, 1-14. [CrossRef]

27. The Guardian. Shell Says it Wants to Double Green Energy Investment. Available online: https://www. theguardian.com/business/2018/dec/26/shell-says-it-wants-to-double-green-energy-investment (accessed on 27 November 2019).

28. Scott, W.R. Institutions and Organizations; Sage: Thousand Oaks, CA, USA, 1995.

29. Scott, W.R. Institutions and Organizations: Ideas, Interests, and Identities, 4th ed.; Sage: Thousand Oaks, CA, USA, 2014.

30. Katz, E. Theorizing Diffusion: Tarde and Sorokin Revisited. Ann. Am. Acad. Political Soc. Sci. 1999, 566, 144-155. [CrossRef]

31. Terlaak, A.; Gong, Y. Vicarious Learning and Inferential Accuracy in Adoption Processes. Acad. Manag. Rev. 2008, 33, 846-868. [CrossRef]

32. Ansari, S.M.; Fiss, P.C.; Zajac, E. Made to fit: How practices vary as they diffuse. Acad. Manag. Rev. 2010, 35, 67-92. [CrossRef] 
33. Busenitz, L.W.; Gómez, C.; Spencer, J.W. Country Institutional Profiles: Unlocking Entrepreneurial Phenomena. Acad. Manag. J. 2000, 43, 994-1003. [CrossRef]

34. Åmo, B.W.; Bullvåg, E.; Oftedal, E.M. The influence from the organizational climate on employee innovation behavior. Front. Entrep. Res 2006, 26, 10.

35. Oftedal, E.M. Legitimacy for Creative Destruction: A Structure-Agent Perspective of Entrepreneurship; Handelshøgskolen i Bodø: Bodø, Norway, 2008.

36. Oftedal, E.M.; Iakovleva, T.A.; Foss, L. University context matter: An institutional perspective on entrepreneurial intentions of students. Educ. Train. 2018, 60, 873-890. [CrossRef]

37. Bloodgood, J.; Hornsby, J.; Rutherford, M.; McFarland, R. The role of network density and betweenness centrality in diffusing new venture legitimacy: an epidemiological approach. Int. Entrep. Manag. J. 2017, 13, 525-552. [CrossRef]

38. Delmar, F.; Shane, S. Legitimating first: organizing activities and the survival of new ventures. J. Bus. Ventur. 2004, 19, 385-410. [CrossRef]

39. Suddaby, R. Challenges for Institutional Theory. J. Manag. Inq. 2010, 19, 14-20. [CrossRef]

40. Hoerndlein, C.; Benlian, A.; Hess, T. Institutional Influences in Individual-Level Innovation Adoption Outside Organizational Contexts: A Scale Development Study. In Proceedings of the Thirty Third International Conference on Information Systems, Orlando, FL, USA, 16-19 December 2012.

41. Ulla de, S. Knowledge Culture. In Organizational Culture and Behavior: Concepts, Methodologies, Tools, and Applications; IGI Global: Hershey, PA, USA, 2017; pp. 1856-1880. [CrossRef]

42. Powell, W.W.; Dimaggio, P.J. Introduction. In The New Institutionalism in Organizational Analysis, Powell, W.W., Dimaggio, P.J., Eds.; University of Chicago Press: Chicago, IL, USA, 1991.

43. Scott, W.R. Institutions and Organizations. Ideas, Interests and Identities. M@n@gement 1995, 17, 136. [CrossRef]

44. Scott, W.R. The Adolescence of Institutional Theory. Adm. Sci. Q. 1987, 32, 493-511. [CrossRef]

45. Selznick, P. Leadership in Administration; Harper \& Row: New York, NY, USA, 1957.

46. Lounsbury, M.; Crumley, E.T. New Practice Creation: An Institutional Perspective on Innovation. Organ. Stud. 2007, 28, 993-1012. [CrossRef]

47. Schein, E.H. The role of the founder in creating organizational culture. Organ. Dyn. 1983, 12, $13-28$. [CrossRef]

48. Hofman, P.S.; Elzen, B. Exploring system innovation in the electricity system through sociotechnical scenarios. Technol. Anal. Strateg. Manag. 2010, 22, 653-670. [CrossRef]

49. Cruz-Suárez, A.; Prado-Román, C.; Díez-Martín, F. Por qué se institucionalizan las organizaciones. Rev. Eur. Dir. Econ. Empresa 2014, 23, 22-30. [CrossRef]

50. Díez de Castro, E.P.; Díez Martín, F.D.A.; Vázquez Sánchez, A.E. Antecedentes de la institucionalización de las organizaciones. Cuad. Gestión. 2015, 15, 15-38. [CrossRef]

51. Alexiou, K.; Wiggins, J. Measuring individual legitimacy perceptions: Scale development and validation. Strateg. Organ. 2019, 17, 470-496. [CrossRef]

52. Díez-de-Castro, E.; Peris-Ortiz, M.; Díez-Martín, F. Criteria for Evaluating the Organizational Legitimacy: A Typology for Legitimacy Jungle. In Organizational Legitimacy: Challenges and Opportunities for Businesses and Institutions; Díez-De-Castro, E., Peris-Ortiz, M., Eds.; Springer International Publishing: Cham, Switzerland, 2018; pp. 1-21. [CrossRef]

53. Munir, K.A. Being Different: How Normative and Cognitive Aspects of Institutional Environments Influence Technology Transfer. Hum. Relat. 2002, 55, 1403-1428. [CrossRef]

54. Dart, R. The legitimacy of social enterprise. Nonprofit Manag. Leadersh. 2004, 14, 411-424. [CrossRef]

55. Goulden, S.; Portman, M.E.; Carmon, N.; Alon-Mozes, T. From conventional drainage to sustainable stormwater management: Beyond the technical challenges. J. Environ. Manag. 2018, 219, 37-45. [CrossRef] [PubMed]

56. Outsios, G. Gender in sustainable entrepreneurship: Evidence from the UK. Gend. Manag. Int. J. 2017, 32, 183-202. [CrossRef]

57. Polk, M. The influence of gender on daily car use and on willingness to reduce car use in Sweden. J. Transp. Geogr. 2004, 12, 185-195. [CrossRef]

58. Geels, F.W. From sectoral systems of innovation to socio-technical systems: Insights about dynamics and change from sociology and institutional theory. Res. Policy 2004, 33, 897-920. [CrossRef] 
59. Scott, W.R. Institutions and Organizations: Ideas and Interests; Sage: Thousand Oaks, CA, USA, 2008.

60. Nilsen, T. Innovation from the inside out: Contrasting fossil and renewable energy pathways at Statoil. Energy Res. Soc. Sci. 2017, 28, 50-57. [CrossRef]

61. Wilks, N. Oil and gas special: Offshore industry goes green. Prof. Eng. 2011, 24. Available online: https://www.onacademic.com/detail/journal_1000029716629299_8771.html (accessed on 8 January 2020).

62. Brundtland, G.H. Report of the World Commission on Environment and Development: Our Common Future; Oxford University Press: Oxford, UK, 1987.

63. Norwegian Ministry of Climate and Environment (KLD). Norway's Sixth National Communication, Under the Framework Convention on Climate Change; KLD: Oslo, Norway, 2014.

64. Chaiyapa, W.; Esteban, M.; Kameyama, Y. Why go green? Discourse analysis of motivations for Thailand's oil and gas companies to invest in renewable energy. Energy Policy 2018, 120, 448-459. [CrossRef]

65. Hipp, J.R.; Bollen, K.A. Model Fit in Structural Equation Models with Censored, Ordinal, and Dichotomous Variables: Testing Vanishing Tetrads. Sociol. Methodol. 2003, 33, 267-305. [CrossRef]

66. Lubke, G.H.; Muthen, B.O. Applying Multigroup Confirmatory Factor Models for Continuous Outcomes to Likert Scale Data Complicates Meaningful Group Comparisons. Struct. Equ. Model. 2004, 11, 514-534. [CrossRef]

67. Fan, Y.; Chen, J.; Shirkey, G.; John, R.; Wu, S.R.; Park, H.; Shao, C. Applications of structural equation modeling (SEM) in ecological studies: an updated review. Ecol. Process. 2016, 5, 19. [CrossRef]

68. Schumacker, R.E.; Lomax, R.G. A Beginner's Guide to Structural Equation Modeling, 2nd ed.; Lawrence Erlbaum Associates: Mahwah, NJ, USA, 2004.

69. Sijtsma, K.; Straat, J.H.; van der Ark, L.A. Goodness-of-Fit Methods for Nonparametric IRT Models. In Quantitative Psychology Research. Springer Proceedings in Mathematics E Statistics; van der Ark, L.A., Bolt, D.M., Wang, W.-C., Douglas, J.A., Chow, S.-M., Eds.; Springer Nature: Cham, Switzerland, 2015; pp. 109-120. [CrossRef]

70. MacKenzie, S.B.; Podsakoff, P.M.; Podsakoff, N.P. Construct Measurement and Validation Procedures in MIS and Behavioral Research: Integrating New and Existing Techniques. MIS Q. 2011, 35, 293-334. [CrossRef]

71. Buchanan, D.A.; Bryman, A. Contextualizing Methods Choice in Organizational Research. Organ. Res. Method 2007, 10, 483-501. [CrossRef]

72. Weijters, B.; Cabooter, E.; Schillewaert, N. The effect of rating scale format on response styles: The number of response categories and response category labels. Int. J. Res. Mark. 2010, 27, 236-247. [CrossRef]

73. Yong, A.G.; Pearce, S. A beginner's guide to factor analysis: Focusing on exploratory factor analysis. Tutor. Quant. Methods Psychol. 2013, 9, 79-94. [CrossRef]

74. Gaskin, J. SEM Series (2016) 3. Exploratory Factor Analysis (EFA). Available online: https://www. youtube.com/watch?v=VBsuEBsO3U8\&list=PLnMJlbz3sefJaVv8rBL2_G85HoUko5I--\&index=3 (accessed on 26 October 2018).

75. Gallagher, M.W.; Brown, T.A. Introduction to Confirmatory Factor Analysis and Structural Equation Modeling. In Handbook of Quantitative Methods for Educational Research; Teo, T., Ed.; SensePublishers: Rotterdam, The Netherlands, 2013; pp. 289-314. [CrossRef]

76. Podsakoff, P.M.; Mackenzie, S.B.; Lee, J.-Y.; Podsakoff, N.P. Common Method Biases in Behavioral Research: A Critical Review of the Literature and Recommended Remedies. J. Appl. Psychol. 2003, 88, 879-903. [CrossRef]

77. Gaskin, J. Excel StatTools. Available online: http://statwiki.kolobkreations.com/index.php?title=Main_Page (accessed on 20 August 2018).

78. Hair, J.F.; Black, W.C.; Babin, B.J.; Anderson, R.E. Multivariate Data Analysis: Pearson New International Edition; Pearson Education Limited: Harlow, UK, 2013.

79. Kenny, D.A.; Kaniskan, B.; McCoach, D.B. The Performance of RMSEA in Models With Small Degrees of Freedom. Sociol. Methods Res. 2014, 44, 486-507. [CrossRef]

80. Tracey, J.B.; Tews, M.J. Construct Validity of a General Training Climate Scale. Organ. Res. Methods 2005, 8, 353-374. [CrossRef]

81. Kock, N. Common method bias in PLS-SEM: A full collinearity assessment approach. Int. J. E-Collab. 2015, 11,1-10. [CrossRef]

82. O'brien, R.M. A Caution Regarding Rules of Thumb for Variance Inflation Factors. Qual. Quant. 2007, 41, 673-690. [CrossRef] 
83. Loken, E.; Gelman, A. Random measurement error and the replication crisis: A statistical analysis. Science 2017, 335, 584-585. [CrossRef]

84. Golant, B.D.; Sillince, J.A.A. The Constitution of Organizational Legitimacy: A Narrative Perspective. Organ. Stud. 2007, 28, 1149-1167. [CrossRef]

85. Greenwood, R.; Suddaby, R. Institutional Entrepreneurship in Mature Fields: The Big Five Accounting Firms. Acad. Manag. J. 2006, 49, 27-48. [CrossRef]

86. Schneiberg, M.; Lounsbury, M. Social movements and institutional analysis. In Handbook of Organizational Institutionalism; Greenwood, R., Oliver, C., Sahlins, K., Suddaby, R., Eds.; SAGE Publications: London, UK, 2008; pp. 648-670.

87. Zietsma, C.; Lawrence, T. Institutional Work in the Transformation of an Organizational Field: The Interplay of Boundary Work and Practice Work. Adm. Sci. Q. 2010, 55, 189-221. [CrossRef]

88. Laifi, A.; Josserand, E. Legitimation in practice: A new digital publishing business model. J. Bus. Res. 2016, 69, 2343-2352. [CrossRef]

89. Haack, P.; Schoeneborn, D.; Wickert, C. Talking the Talk, Moral Entrapment, Creeping Commitment? Exploring Narrative Dynamics in Corporate Responsibility Standardization. Organ. Stud. 2012, 33, 815-845. [CrossRef]

(C) 2020 by the authors. Licensee MDPI, Basel, Switzerland. This article is an open access article distributed under the terms and conditions of the Creative Commons Attribution (CC BY) license (http://creativecommons.org/licenses/by/4.0/). 